\title{
ІДЕЇ СКОВОРОДИ У ЗДОРОВ'ЯЗБЕРІГАЮЧІЙ ФІЛОСОФІї СУЧАСНОГО СУСПІЛЬСТВА
}

\author{
Л. В. Кравчук, С. В. Бондаренко,Т. Б. Кадобний
}

ДВНЗ “Тернопільський державний медичний університет імені І. Я. Горбачевського МОЗ Украӥни”

\section{SKOVORODA'S IDEAS IN HEALTHPRESERVING PHILOSOPHY OF MODERN SOCIETY}

\author{
L. V. Kravchuk, S. V. Bondarenko, T. B. Kadobnyi \\ SHEI "Ternopil State Medical University by I. Ya. Horbachevsky of MPH of Ukraine”
}

\begin{abstract}
Звернено увагу на актуальність та значимість духовних, моральних, принципів, що відображені в творчості українського філософа-мудреця Г. С. Сковороди, які доцільно використовувати у підготовці студентів-медиків, формуючи їх світогляд та життєві позиції у процесі навчання на засадах гуманності та добродіяння.
\end{abstract}

The article adduces the urgency and significance of cultural and moral principles reflected in the creative work of the Ukrainian philosopher-sage H. S. Skovoroda that can be reasonably used in training of medical students to form their world outlook and vital positions in the process of studying on the bases of humanity and benefaction.

Вступ. Будь-який поступ уперед можливий при концентрації духовних, моральних і фізичних зусиль, або при величезному внутрішньому прагненні, яке формується на базі названих чинників, що мобілізують всі сфери життедіяльності до поступу. Чим свідоміше і активніше ці риси діють у суспільстві, тим міцнішими і удосконаленими будуть його внутрішні і зовнішні позиції, а звідси захищені і убезпечені його інтереси.

Сковорода соціальний прогрес ставив у залежність від пізнання і розвитку духовних, моральних цінностей людини. На його думку, розвиток науки і техніки ще не розв'язує потребу людського щастя [1]. Не можна допустити зупинки "Великого двигуна духовного розвитку” [2]. Щоб зрозуміти природу труднощів на шляху до вдосконалення суспільства, необхідно збагнути першопричину того, що відбувається сьогодні, а для цього необхідно звернутися до першоджерел національної духовності, з яких пили і самі наповнювали наші великі предки. Знати їх, пам'ятати їх, та зберегти свою духовну силу і мати непохитним своє душевне здоров'я, а значить здобувати у своєму розвитку. Саме спадщина Сковороди $є$ тим основним фундаментом, 3 якого вибудовуються міцні основи української духовності, яка спроможна об'єднати і зоорганізувати все суспільство в єдиному устремлінні розбудови власної держави, упираючись на національні резерви та досвід. Тільки через наполегливість і вірність, духовність і щирість, любов і доброзичливість можна досягти взаємопорозуміння, а отже, згоди у всіх великих і малих справах.

Григорій Сковорода - символ і творець української мудрості. "Мудрість" - широка, як земля, світлом яка до неба подібна [3], яку не відділяв від філософії, як розум не відділяв від серця. Його філософія - це філософія серця, як і вся українська філософія: істину сприймає і розумом, і серцем, і навіть 3 пріоритетом серця над розумом.

Серце, як і думка, $\epsilon$ те духовне начало та "невидима натура", яка визначає в людині їі “"головне”. Воно, серце, власне, i “ $є$ точно людина”, “справжня людина" [4].

Виходець 3 козацько-селянської родини. Батьківщина - Лубенщина, що на Полтавщині. 3 двома перервами навчався в Києво-Могилянській академії, котрої так і не закінчив: його гордий дух не мирився 3 суворими академічними порядками... Опісля був співаком у Петербурзькій придворній капелі, домашнім вчителем, викладав у коледжі і працював у складі посольської місії в Угорщині. I мандрував його мандри пролягли дорогами рідної України, а також Росії, Словенії, Польщі, Австрії, Німеччини, Італії.

Похований на Харківщині, в селі Іванівка (нині Сковородинівка). Його творчість не просто багата, а

() Л. В. Кравчук, С. В. Бондаренко,Т. Б. Кадобний 
безцінна. I в масі своїй ще не вивчена, а тому, змушені визнати, маловідома. Це один з наших національних духовних порадників - ми майже не знаємо свого класика... Однак назвемо його найголовніші твори: збірка “Сад божественних пісень” та "Байки Харківські", трактати "Начальная дверь до християнського добронравія", "Нарисе Розглагол о том узнай себе”, “Розмова п’яти путників об істинном щастії в жизні”, "Розмова, названа Алфавіт, або Буквар світу”, “Діалог. Ім'я йому - поток зміїний”, “Ікона Алкивіадська", “Брань архистратига Михаїла із Сатаною" та багато інших.

Сковорода переконаний, що мудрість дана людині для того, щоб вона утверджувала добро через творення “внутрішньої людини” і долала зло через руйнування “зовнішньої людини”. Божа мудрість “розливається по тілу, робить його сильнішим” [5]. Сковорода вбачав дві людини в людині одній - “пан” і “слуга" [6]. I сьогодні в роботі зі студентською молоддю як в теорії, так і у практиці ниткою Аріадни має стати сковоридизація моральних, фізичних, духовних інтересів та їх поглядів на життя.

Сковорода добре розумів, що проблема людини найскладніша і найважча [5].

Джерелом добра є істинне розуміння суті речей $і$ процесів, з яких виростають віра і сила, що формують істину і свободу.

Джерелом зла є хибне розуміння (або нерозуміння) суті речей і явищ, з якого випливають безглуздя і слабкість, що реформують у хибу й рабство.

3 цього випливає, що добрі наміри серця спрямовуються для внутрішнього, духовного, тобто істинного світу, а злі, - до зовнішнього, тілесного, тобто хибного світу. Тому духовне пов'язане в Істиною і Свободою, а тілесне - 3 Хибою та Рабством.

Основна частина. Щоб творити добро, себе треба знати. Тому головний об' єкт пізнання - кожен сам собі: як рідна мати знаходиться вдома, так істина i щастя кожного - в кожному самому. Вище щастя це цілковита перемога духу, що дає повний, цілковитий спокій [7]. Пізнати себе - це здобути "радість серця” i “міцність душі”, що приводить до “внутрішнього миру” як злагоди з самим собою і з усім світом.

В “Розмові п'яти путників про істинне щастя в житті” Сковорода заявляє: “Наше бажання верховне в тому, щоб бути щасливим “знає, що шукає щастя, але, не розуміючи, де воно, впадає в неспокій... Життя наше $\epsilon$ шлях, а похід до щастя не короткий. Бути щасливим - впізнати" знайти самого себе... ось вам верхівка і квітка всього життя вашого, внутрішній мир, сердечна веселість, душевна міцність. Сюди спря- мовуйте ваших справ течію... Всяке слово, всяке діло нехай цьому кінцю сприяє. Нехай це буде межею всіх наших думок і всіх твоїх бажань".

А досягається це за допомогою таких душевних станів: евдемінії (щастя) - проголошення щастя вищою метою людського життя, автаркії (самовдоволення) - незалежністю від зовнішнього світу через самозабезпечення потреб; аскези (стриманість) максимальним обмеженням тілесних потреб; апатії (нечуттєвість) - байдужим ставленням до життєвих проблем.

Світ, створений Богом, складається 3 трьох частин: Макрокосму як Всесвіту, Мікрокосму як людини та Світу Символів як Святого Письма (або символів, тайна котрих - в Святому Письмі).

Макрокосм - "Вищий порядок" - це Всесвіт, що відкриває таємниці Божественної творчості, бо все створене Богом - то Божі сліди, а сам світ - Божий храм, ним самим збудований.

Мікрокосм - "Малий порядок” - створена Богом людина, котра є двонатурною: внутрішня - iіi духовний світ, що єднаєії з Богом, та зовнішня - iї тілесність, що єднає їі зі світом, в якому вона живе. Справжній світ - духовний, і тут - істинне серце. Зовнішня людина - ілюзорна природа, лише видима маска плоті.

Символічний світ є світом біблійних символів, які дають ключ до розкриття тайн Макрокосму і Мікрокосму, які обидва є творіннями Божими, а Біблія даром Божим для осягнення людиною цих творінь. Кожен символ - це сходинка в сходженні до Істини й Бога, а читати Біблію - це читати світ, розуміти його i себе, духовно наближатись до Господа.

В трактаті "Наркісс. Розглагол о том: узнай себе" Григорій Сковорода пише: “Бог єдиний нам всю істину освітлює. Тоді бачимо порожню мрію, побачивши істину і зрозумівши юність, розуміємо старість. Земна людина думає про себе, ніби щось розуміє... Чи не всякому знайомі слова: час, життя, смерть, благодать, любов, мисль, душа, пристрасть, совість, вдячність? Нам здається, що розуміємо. Але якщо в когось запитати пояснення, тоді всякий задумається. Хто може пояснити, що означає час, якщо не проникне в Божественну висоту? Початок премудрості - розуміння Господа.. Просвітлений тайнами божества, розумієш, чого хочеш...”

Отже, пізнання світу - це пізнання, насамперед, самого себе, а пізнання - це пошук "царства Божого" в собі самому, а це, в свою чергу - "переображення" свого серця - повернення йому “образу” Божого, а всьому собі - “подоби” Божої. Образ Божий - в серці, дитя Боже - в діях, - такою має бути лю- 
дина, яка бажає збудувати в собі “внутрішнє” християнство, тобто зректись зовнішнього, ілюзорного, $\mathrm{i}$ повернутись до внутрішнього, вічного.

“Внутрішня" людина здатна лише до високої моралі, бо вона живе “за натурою”, що означає: така людина знайшла своє місце в житті, тобто знайшла “свій сродний труд” (“споріднену працю”), для якого iii створив Бог. Зрозуміти свою природу, знайти свою “споріднену працю” - це запорука духовного самовдосконалення, щастя в житті і гармонії зі світом.

У трактаті "Розмова, названа алфавіт, або Буквар світу” Григорій Сковорода пояснює: “Багато хто, потоптавши природу, вибирає для себе ремесло наймодніше й найприбутковіше, але сим вони лише ошукують себе. Прибуток не є утіха, але мусить слугувати для задоволення тілесних потреб, а коли це й утіха, то не для серця, утіху для серця матимете у спорідненій праці. Тим ся справа приємніша, чим спорідненіша. Коли б утіха була від розкоші, то чи було б так мало багатих? Але спокійніших і бадьорих серед них мало. Божеством живиться лише тіло, а душу звеселяє споріднена праця".

В іншому місці цієї ж праці продовжує: "Мова моя тоді спокійніша, коли кожна людина не лише добра, але і споріднену собі усіма сторонами знаходить роботу. Се і є бути щасливим, пізнати себе чи свою природу, взятися за своє споріднене діло і бути з ним у злагоді з загальною потребою. Така потреба - це благодійство і послуга...

Найдобріша людина тим неспокійніша і нещасніша, чим більшу посаду вона займає, але до неї не народжена... Як не буде погано, коли немає завзятості і невтомної праці? Звідки ж з'явиться працелюбність, коли немає бажання і старанності? Де ж візьмеш бажання без природи? Природа - всьому початкова причина і рушійна сила. Вона і є матір'ю бажання. Бажання ж - започаткування, схильність і рух. Бажання, за приказкою, сильніше неволі. Воно прагне до праці і радіє з неї, як зі свого сина. Праця живий і невсипущий рух усієї машини, доки не довершиться справа, що сплітає творцеві вінець радості. Коротко кажучи, природа наснажує до діла і зміцнює до праці, роблячи їі солодкою...”,

Однак люди різняться між собою не лише за видом “спорідненої праці”, а й за творчими задатками, за ступенем обдарованості. Сковорода стверджує: "Бог подібний до фонтана, який наповнює різноманітні за місткістю посудини. Над фонтаном напис "Нерівна всім рівність", а це означає, що “менша посудина менше має, але в тім рівна більшість, що є повною”. Тому намагатись досягти “рівної рівності" $\epsilon$ чистим безглуздям, бо рівність людей з різними можливостями та потребами неможлива. Бо людина, як своєрідна посудина, може бути наповненою лише настільки, наскільки має об'єму - не більше. Справедливим $є$ не обсяг наповнення, а факт наповненості. Тому справедливість і благо там, де створені для кожного умови займатися своєю “спорідненою працею”, перебувати на своєму місці в житті - тільки за такої умови досягнеться гармонія душевного блаженства і тілесної благодаті.

Прочитаймо 21 байку з його “Байок Харківських": "Робота наша - джерело радості. А коли кого своя робота не звеселяє, той, звичайно, ій не родич і не їі вірний приятель, але щось біля неї любить, і як неспокійний, та і не щасливий. Але немає нічого солодшого, як спільна для нас усіх робота. Вона є голова, світло і сіль будь-якого окремого заняття... Щасливий той, хто поєднав любе собі заняття із загальним. Воно є справжнє життя. І тепер можна зрозуміти таке Сократове слово: “Дехто живе для того, щоб їсти й пити, а я їм і п’ю для того, щоб жити”.

Висновки. Людина могутня своїм розумом, який дає їй величезні можливості впливу на зовнішній світ, але це не робить іï достатньо щасливою, бо, маючи під собою світ, людина не знає як слід себе самої, відчуває внутрішній “голод і спрагу”. Знання зовнішнього світу не дає головного - душевної рівноваги і внутрішнього спокою. Тож справжнє щастя і благо людини - в ній самій, але аж ніяк не поза нею.

“В город не піду багатий - у полях я буду жить,

Вік свій буду коротати там, де тихо час біжить...

Бо міста, хоча й високі, в море розпачу штовхнуть,

А ворота і широкі у неволю заведуть...

Дух мій і наук не хоче проти розуму свого,

Крім Христа святих пророчень - раю чистого мого...

I нічого не бажаю, окрім хліба та води,

Вбогість я за друга маю, з нею ми давно свати..

Мій маєток прежаданий - спокій, воленька свята, Окрім вічності для мене лиш дорога ця свята".

А найголовніше - і в цьому серцевина сковородинської мудрості! - ось в чому: "Главою діл людських є дух їі, думки, серце... Коли дух в людини веселий, думки спокійні, серце мирне, то все є світлим, щасливим, блаженним. Се і є філософія”.

І в цьому є Григорій Сковорода - творець і класик української мудрості - мудрості сердечної. Як вся українська духовна культура.

Отже, духовний світ людини - це той головний ресурс, який допомагає долати труднощі, що зустрічаються на життєвих шляхах, так і основний двигун, що 
сприяє і підсилює розвиток кращих рис людини, допомагає вибрати найоптимальніший режим навантажень, правильну стратегію життєдіяльності по відношенню людини до людини, людини до колективу, до природи, до суспільства в цілому. Особливо, коли доводиться формувати професійні навики і життєвий світогляд у студентів-медиків, робота яких виключно буде з часом продовжуватись у тісному контакті з людським масивом. I тому, наскільки свідомо і правильно будуть засвоєні ці сковородівські принципи відносин між людьми, настільки буде збережено і розвинуте моральне, духовне і фізичне здоров'я суспільства, зміцнені його позиції як усередині країни, так і захищені зовнішні інтереси. А отже, здоров'язберігаючі

\section{Література}

1. Шинкарук В. І. Філософія Григорія Сковороди / В. І. Шинкарук. -К., 1972.-309 с.

2. Мишанич О. В. Григорій Сковорода і усна народна творчість / О. В. Мишанич. -К., 1976. - 150 с.

3. Шевчук В. Пізнаний і непізнаний сфінкс Григорій Сковорода сучасними очима. Роздуми / В. Шевчук. -К., 2008. $-525 \mathrm{c}$.

4. Барабаш Ю. “Знаю человека...” Григорий Сковорода: поэзия, философия, жизнь / Ю. Барабаш. -М., 1989. -333 с. технології потребують особливої уваги в освітньо-виховній та фаховій діяльності викладач-студент. Сьогодні це є однією з найактуальніших вимог часу. Правильно підготовлене і виховане молоде покоління -це найбільший скарб для батьків, суспільства і держави. Вся діяльність навчально-виховного циклу повинна спрямовуватись на правильне формування основних життєвих цінностей у підлітковому віці, які допоможуть зміцнити і зробити природу майбутньої молодої людини набагато кращою, досконалішою, а значить, готовою і спроможною творити, як заповідав Григорій Сковорода, добро.

Копай всередині себе колодязь для тієї води, яка зросить і твій дім і сусідський [8].

5. Горбач. Н. Невідомий Сковорода / Н. Горбач. - Л., 2002.-150 c.

6. Редько М. П. Видатний філософ - гуманіст (до 250річчя з дня Г. С. Сковороди) / М. П. Редько. -К., 1972. -47 с.

7. Баглій Д. Український мандрівний філософ Григорій Сковорода / Д. Баглій. -К., 1992. -469 с.

8. Ольшанський І. Григорій Сковорода. Місія посланця / I. Ольшанський. - Луцьк, 2008. - 158 с. 